\title{
The antiestrogen 4-hydroxytamoxifen protects against isotretinoin-induced permeability transition and bioenergetic dysfunction of liver mitochondria: comparison with tamoxifen
}

\author{
Filomena S. G. Silva • Mariana P. C. Ribeiro • \\ Maria S. Santos • Petronila Rocha-Pereira • \\ Alice Santos-Silva • José B. A. Custódio
}

Received: 23 February 2013 / Accepted: 21 May 2013 / Published online: 19 June 2013

(C) Springer Science+Business Media New York 2013

\begin{abstract}
The combination of isotretinoin (13-cis-retinoic acid) with antiestrogens seems to be a promising strategy for cancer chemotherapy. The aim of the study was to evaluate the effects of isotretinoin alone or in combination with 4-hydroxytamoxifen (OHTAM) and with its prodrug tamoxifen (TAM), on the functions of rat liver
\end{abstract}

F. S. G. Silva • M. P. C. Ribeiro • M. S. Santos • J. B. A. Custódio Center for Neuroscience and Cell Biology, University of Coimbra, Coimbra, Portugal

F. S. G. Silva • M. P. C. Ribeiro • J. B. A. Custódio Institute of Biochemistry, Faculty of Pharmacy,

University of Coimbra, Coimbra, Portugal

\section{S. Santos}

Department of Life Sciences, Faculty of Sciences and Technology, University of Coimbra, Coimbra, Portugal

\section{P. Rocha-Pereira}

Health Sciences Research Centre, University of Beira Interior, Covilhã, Portugal

\section{A. Santos-Silva}

Department of Biological Sciences, Biochemical Laboratory, Faculty of Pharmacy, University of Porto, Porto, Portugal

P. Rocha-Pereira $\cdot$ A. Santos-Silva

Institute of Cell and Molecular Biology, University of Porto,

Porto, Portugal

J. B. A. Custódio $(\bowtie)$

Pólo das Ciências da Saúde, Azinhaga de Santa Comba, 3000-295, Coimbra, Portugal

e-mail: custodio@ci.uc.pt mitochondria, i.e., mitochondrial permeability transition (MPT), bioenergetic functions and adenine nucleotide translocase (ANT). Isotretinoin $(5 \mathrm{nmol} / \mathrm{mg}$ protein) induced the $\mathrm{Ca}^{2+}$-dependent MPT pore opening in mitochondria energized with succinate, which was prevented by OHTAM, cyclosporine A, TAM and ANT ligands. When mitochondria were energized with glutamate/malate and in the absence of added $\mathrm{Ca}^{2+}$ isotretinoin decreased the state 3 respiration, the ATP levels, the active ANT content and increased the lag phase of the phosphorylation cycle, demonstrating that isotretinoin decreased the mitochondrial phosphorylation efficiency. These changes of isotretinoin in bioenergetic parameters were not significant in the presence of succinate. The effects of isotretinoin at $5 \mathrm{nmol} / \mathrm{mg}$ protein on the $\mathrm{Ca}^{2+}$-dependent MPT and phosphorylative efficacy may be related with interactions with the ANT. Above $10 \mathrm{nmol} / \mathrm{mg}$ protein isotretinoin strongly diminished the active ANT content, decreased the $\Delta \psi$, inhibited the complex I and induced proton leak through the Fo fraction of complex V. The combination of OHTAM with isotretinoin only induced significant changes in the energy production systems at concentrations $\geq 5 \mathrm{nmol}$ isotretinoin $/ \mathrm{mg}$ protein. Therefore, our results suggest that isotretinoin-associated liver toxicity is possibly related with mitochondrial dysfunctions and that the combination with OHTAM may contribute to decrease its toxicity.

Keywords Isotretinoin · 4-hydroxytamoxifen · Tamoxifen · Oxidative phosphorylation system $\cdot$ Mitochondrial permeability transition 


$\begin{array}{ll}\text { Abbreviations } \\ \text { ANT } & \text { Adenine nucleotide translocase } \\ \text { Asc } & \text { Ascorbate } \\ \text { CAT } & \text { Carboxyatractyloside } \\ \text { CyA } & \text { Cyclosporine A } \\ \text { Cys } & \text { Cysteine } \\ \text { DTT } & \text { Dithiothreitol } \\ \text { FCCP } & \text { Carbonyl cyanide } p \text { - } \\ & \text { trifluormethoxyphenylhydrazone } \\ \text { MPT } & \text { Mitochondrial permeability transition } \\ \text { NAC } & N \text {-acetylcysteine } \\ \text { NEM } & N \text {-ethylmaleimide } \\ \text { OHTAM } & \text { 4-hydroxytamoxifen } \\ \text { TAM } & \text { Tamoxifen } \\ \text { TPP } & \text { Tetraphenylphosphonium } \\ \text { RAR } & \text { Retinoic acid receptor } \\ \text { RCR } & \text { Respiratory control ratio } \\ \text { RXR } & \text { Retinoid X receptor } \\ \Delta \psi & \text { Mitochondrial membrane potential }\end{array}$

\section{Introduction}

Isotretinoin (13-cis-retinoic acid), structurally related to vita$\min \mathrm{A}$, is a first-generation retinoid often used for the treatment of many inflammatory skin disorders, and its use in the treatment of some cancers is currently under investigation (Njar et al. 2006; Norris et al. 2011; Pili et al. 2012). This compound achieves its remarkable efficacy by interfering with cell-cycle progression, cellular differentiation, cell survival and apoptosis in different cell types, including human breast cancer cells (Toma et al. 1997; Czeczuga-Semeniuk et al. 2001), hepatoma (Arce et al. 2005) and melanoma cells (Lotan et al. 1980; Niu et al. 2005; Guruvayoorappan et al. 2008). It has been described that the inhibition of cancer cell growth by isotretinoin is mediated through the nuclear retinoid receptors, i.e., retinoic acid receptor (RAR) and retinoid X receptor (RXR) (Chambon 1996). However, it has been hypothesized that isotretinoin acts independently of the nuclear retinoid receptor pathway (Sabichi et al. 2003), as suggested by the multiple side effects observed in patients treated with isotretinoin (Goodfield et al. 2010; Sardana \& Garg 2011). In addition, cell culture studies showed that isotretinoin induces several changes in mitochondria, such as a decrease in the expression of the antiapoptotic protein Bcl-2 (Guruvayoorappan et al. 2008; Vuletic et al. 2010) and the activation of caspase-3 (Arce et al. 2005; Guruvayoorappan et al. 2008) leading to cell death by apoptosis. It was also reported that isotretinoin (at concentrations from 4 to $33 \mu \mathrm{M}$ or 16 to $132 \mathrm{nmol} / \mathrm{mg}$ protein) induces mitochondrial permeability transition (MPT) pore opening and the release of the cytochrome $c$ (Rigobello et al. 1999). These results suggest that mitochondria may be involved in the toxicological effects induced by this retinoid.
The RARs are members of the thyroid-retinoid receptors family and have a basic structure that is also present in other nuclear receptors, such as the estrogen receptors (ER) (Chambon 1996). It has been proposed that both RAR and ER take part of a "cross talk" pathway, as the inhibition of breast tumor cell growth by retinoids is more pronounced for ER-positive cells (Simeone \& Tari 2004). Furthermore, RAR activated appear to exert anti-estrogenic effects by directly or indirectly link the ER to estrogen response elements (EREs) (Demirpence et al. 1994). Conversely, the N-terminal region of $\mathrm{ER} \alpha$ modulates the transcriptional activity of RAR (Rousseau et al. 2003). More recently, different works have demonstrated that retinoic acid receptor $\alpha(\operatorname{RAR} \alpha)$ is probably an essential component of the ER (Ross-Innes et al. 2010), and that these two nuclear receptors cooperate for effective transcriptional activity in breast cancer cells (Ross-Innes et al. 2010; Hua et al. 2009). These findings suggest the existence of an interplay between retinoid and estrogen signaling, and that the combination of isotretinoin with antiestrogenic compounds may be a promising therapy. In fact, it has been observed a synergistic action between retinoids and tamoxifen (TAM), a nonsteroidal antiestrogenic compound, on breast cancer cell death (Saez et al. 2003; Wang et al. 2007; Searovic et al. 2009). However, TAM is a prodrug with serious side effects (Wong \& Ellis 2004) and patients present a large variation in both therapeutic efficacy and side effects due to CYP3A4 and CYP2D6 polymorphisms (Damodaran et al. 2012). 4hydroxytamoxifen (OHTAM), a major active metabolite, responsible for the anticancer activity of TAM, is a promising compound since this metabolite has a higher affinity for ER, and it is 30- to 200-times more potent than TAM (Lim et al. 2005; Kiyotani et al. 2012). In addition, it is pharmacologically well tolerated (Sauvez et al. 1999) and has less side effects (Cardoso et al. 2002a; Cruz Silva et al. 2001). However, although the combined therapy of antiestrogens with isotretinoin seems to be a good strategy for cancer treatment, the effects of this retinoid in combination with OHTAM or TAM on mitochondria have not been studied.

Considering that mitochondrial damage is a triggering event for deregulation of cell homeostasis (Lemasters et al. 2009; Starkov 2010; Wallace 2008; Fulda et al. 2010), mitochondria fractions are a useful in vitro model to investigate drug toxicity/safety (Labbe et al. 2008). Therefore, the purpose of this study was to evaluate the combined action of OHTAM or TAM with isotretinoin on rat liver mitochondria and the ability of OHTAM and TAM to prevent isotretinoininduced MPT and bioenergetic dysfunction. This study may contribute to clarify the mechanisms of apoptosis and hepatotoxicity promoted by isotretinoin that must always be considered during drug development and even for drugs under therapeutic use (Labbe et al. 2008). 


\section{Materials and methods}

Isolation of rat liver mitochondria

Mitochondria were isolated from the liver of Wistar rats by differential centrifugation as described elsewhere (Gazotti et al. 1979), with slight modifications (Moreira et al. 2006). Rats were killed by cervical dislocation, and their liver was immediately excised and cooled at $4{ }^{\circ} \mathrm{C}$ in the homogenization medium containing $250 \mathrm{mM}$ sucrose, $10 \mathrm{mM}$ 4-(2-hydroxymethyl)-1-piperazineethanesulfonic acid (HEPES) (pH 7.4), 1 mM NNN'N-tetraacetic acid (EGTA) and 0.1\% (w/v) bovine serum albumin (BSA) fat-free. The homogenate was centrifuged at $800 \times g$ for $10 \mathrm{~min}$ and mitochondria were recovered from the supernatant by centrifugation at $10000 \times g$ for $10 \mathrm{~min}$. The EGTA was omitted from the final washing medium and the final mitochondrial pellet was washed twice. Mitochondrial protein concentration was determined by the biuret method using BSA as the protein standard (Gornall et al. 1949).

\section{Mitochondrial membrane potential $(\Delta \psi)$}

The mitochondrial membrane potential $(\Delta \psi)$ was monitored by evaluating the transmembrane distribution of tetraphenylphosphonium $\left(\mathrm{TPP}^{+}\right)$with an ion-selective electrode, prepared according to Kamo et al. (1979), and using a $\mathrm{Ag} / \mathrm{AgCl}_{2}$ electrode as reference (model MI 402; Microelectrodes, Inc., Bedford, NH). The $\Delta \psi$ was estimated from the following equation: $\Delta \psi=59 \times \log (v / V)-$ $59 \times \log \left(10^{\Delta E / 59}-1\right)$, where $v, V$, and $\Delta E$ stand for inner mitochondrial volume, incubation medium volume, and deflection of the electrode potential from the baseline, respectively. A matrix volume of $1.1 \mu \mathrm{l} / \mathrm{mg}$ of protein was assumed. To monitor $\Delta \psi$ associated to mitochondrial respiration, liver mitochondria (1 mg) were incubated at $30{ }^{\circ} \mathrm{C}$ for $3 \mathrm{~min}$, in $2 \mathrm{ml}$ of standard respiratory reaction medium $(130 \mathrm{mM}$ sucrose, $50 \mathrm{mM} \mathrm{KCl}, 5 \mathrm{mM} \mathrm{MgCl} 2,0.1 \mathrm{mM}$ EGTA, $5 \mathrm{mM}$ $\mathrm{KH}_{2} \mathrm{PO} 4,5 \mathrm{mM}$ Hepes, $\mathrm{pH}$ 7.4) supplemented with $4 \mu \mathrm{M}$ $\mathrm{TPP}^{+}$prior to the addition of $5 \mathrm{mM}$ glutamate $/ 2.5 \mathrm{mM}$ malate or $5 \mathrm{mM}$ succinate to energize mitochondria. Isotretinoin was added to the medium after protein addition and incubated for 2 min before starting the reactions. After steady-state distribution of $\mathrm{TPP}^{+}$, ADP (150 nmol/mg protein) was added to initiate state 3 respiration. $\Delta \psi$ was estimated from the decrease of $\mathrm{TPP}^{+}$concentration in the reaction medium.

The $\Delta \psi$ associated to MPT induction was determined with mitochondria $(0.5 \mathrm{mg} / \mathrm{ml})$ incubated in $2 \mathrm{ml}$ of MPT reaction medium (200 mM sucrose, $10 \mathrm{mM}$ Tris-Mops, $1 \mathrm{mM} \mathrm{KH_{2 }} \mathrm{PO}_{4}$ and $10 \mu \mathrm{M}$ EGTA, $\mathrm{pH}$ 7.4) supplemented with $4 \mu \mathrm{M} \mathrm{TPP}{ }^{+}$and $2 \mu \mathrm{M}$ rotenone in the absence and in the presence of $1 \mu \mathrm{M}$ cyclosporine $\mathrm{A}(\mathrm{CyA})$, thiol protecting and antioxidant agents $[1 \mathrm{mM}$ dithiothreitol (DTT), $50 \mu \mathrm{M}$
$N$-ethylmaleimide (NEM), $200 \mu \mathrm{M}$ cysteine (Cys), $200 \mu \mathrm{M}$ $N$-acetylcysteine (NAC), $1 \mathrm{mM}$ ascorbate (Asc) and $1 \mathrm{mM}$ glutathione $(\mathrm{GSH})]$, ANT ligands [ADP $(75 \mu \mathrm{M})$ and ATP $(150 \mu \mathrm{M})]$ and antiestrogenic compounds [TAM and OHTAM $(5 \mu \mathrm{M})]$ before the addition of $5 \mathrm{nmol}$ isotretinoin/mg protein. Mitochondria were energized by the addition of $5 \mathrm{mM}$ succinate and after the steady-state distribution of $\mathrm{TPP}^{+}$has been reached, $\mathrm{Ca}^{2+}(120 \mathrm{nmol} / \mathrm{mg}$ protein) was added and $\Delta \psi$ fluctuations recorded (Custodio et al. 2002). CyA, TAM and OHTAM were also added during the $\Delta \psi$ depolarization as indicated in the figure legends.

Measurements of $\mathrm{Ca}^{2+}$ fluxes

Mitochondrial $\mathrm{Ca}^{2+}$ fluxes were evaluated by monitoring the changes in $\mathrm{Ca}^{2+}$ concentration in the MPT reaction medium by using a $\mathrm{Ca}^{2+}$-sensitive electrode (Madeira 1975; Cardoso et al. 2004). The reactions were carried out with mitochondria (1 mg) in $2 \mathrm{ml}$ of the MPT reaction medium, at $30^{\circ} \mathrm{C}$, in an open vessel, with a constant stirring. The experiments were started by the addition of $5 \mathrm{mM}$ succinate $1 \mathrm{~min}$ after $\mathrm{Ca}^{2+}$ addition (120 nmol/mg protein), in the absence or in the presence of isotretinoin ( $5 \mathrm{nmol} / \mathrm{mg}$ protein) $\left(\mathrm{Ca}^{2+}\right.$ alone). CyA $(1 \mu \mathrm{M})$, thiol protecting and antioxidants agents [DTT (1 mM), NEM (50 $\mu \mathrm{M})$, Cys $(200 \mu \mathrm{M})$, NAC (200 $\mu \mathrm{M})$, Asc $(1 \mathrm{mM})$ and GSH $(1 \mathrm{mM})]$, ANT ligand [ADP $(75 \mu \mathrm{M})]$ and antiestrogenic compounds [TAM and OHTAM $(5 \mu \mathrm{M})]$ were added to the reaction medium $3 \mathrm{~min}$ prior to the addition of isotretinoin.

\section{Mitochondrial oxygen consumption}

Mitochondria (1 mg) were incubated in $1 \mathrm{ml}$ of standard respiratory reaction medium $(130 \mathrm{mM}$ sucrose, $50 \mathrm{mM} \mathrm{KCl}$,

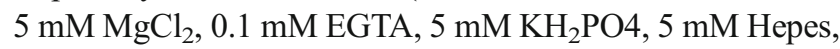
$\mathrm{pH}$ 7.4) in the absence or presence of isotretinoin, TAM and OHTAM. The reactions were performed at $30{ }^{\circ} \mathrm{C}$ in a closed chamber fitted with a Clark-type oxygen electrode (YSI model 5331, Yellow Spring Inst.) and the drugs were added to the respiratory medium and incubated with mitochondria for 2 min before starting the reactions. Respiration state 3 was initiated by the addition of ADP ( $200 \mathrm{nmol} / \mathrm{mg}$ protein), after energization with $5 \mathrm{mM}$ glutamate $/ 2.5 \mathrm{mM}$ malate or succinate. When succinate was used as the respiratory substrate, the medium was supplemented with $2 \mu \mathrm{M}$ rotenone. After phosphorylation of all the ADP added, the oxygen consumption rate decreased and state 4 respiration was resumed. The state 4 oligomycin (state 4 olig) was induced by the addition of oligomycin ( $1 \mu \mathrm{g} / \mathrm{mg}$ protein) plus ADP to evaluate the proton leak through the Fo fraction of complex $\mathrm{V}$ of the respiratory chain. $p$-trifluormethoxyphenylhydrazone (FCCP)-uncoupled respiration was promoted by the addition of FCCP $(1 \mu \mathrm{M})$. Respiration rates were calculated assuming 
an oxygen concentration of $240 \mathrm{nmol} \mathrm{O}_{2} / \mathrm{ml}$ at $30{ }^{\circ} \mathrm{C}$. The respiratory control ratio (RCR) was calculated by the ratio between state 3 and state 4 respirations and ADP/O by the ratio between the amount of ADP added and the $\mathrm{O}_{2}$ consumed during state 3 respiration, as reported by Chance and Williams (Chance \& Williams 1956).

\section{HPLC determination of adenylates}

Adenine nucleotides (ATP and ADP) were extracted using an acidic extraction procedure and were separated by reverse-phase HPLC (Stocchi et al. 1985). The acidic extraction was performed, as follows: mitochondria $(1 \mathrm{mg})$ were incubated in $1 \mathrm{ml}$ standard respiratory reaction medium (130 mM sucrose, $50 \mathrm{mM} \mathrm{KCl}, 5 \mathrm{mM} \mathrm{MgCl} 2,0.1 \mathrm{mM}$

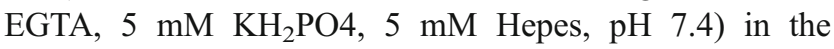
absence (control) or in the presence of isotretinoin. After the incubation period $(2 \mathrm{~min}), 5 \mathrm{mM}$ glutamate $/ 2.5 \mathrm{mM}$ malate was added to induce the state 2 respiration and, 2 min later, the state 3 respiration was induced by the addition of $150 \mathrm{nmol}$ ADP. After 1 min reaction, $250 \mu \mathrm{L}$ of the suspension were added to $250 \mu \mathrm{L}$ ice-cooled $\mathrm{HClO}_{4}$ $0.6 \mathrm{M}$ (EDTA-Na $25 \mathrm{mM}$ ). This mixture was centrifuged at $10000 \mathrm{rpm}$ for $2 \mathrm{~min}$ at $4{ }^{\circ} \mathrm{C}$ and the supernatants were neutralised with $\mathrm{KOH} 3 \mathrm{M}$ and Tris $1.5 \mathrm{M}$. The samples were centrifuged at $10000 \mathrm{rpm}$ for $2 \mathrm{~min}$ and stored at $-80{ }^{\circ} \mathrm{C}$ until chromatographic analysis. All the extraction procedure was carried out at $0-4{ }^{\circ} \mathrm{C}$ to minimize degradation of nucleotides. The chromatographic apparatus used was a Beckman System Gold, consisting of a 126 Binary Pump Model and a 166 Variable UV detector controlled by computer. The protocol used consisted of an isocratic elution with $100 \mathrm{mM} \mathrm{KH}_{2} \mathrm{PO}_{4}, \mathrm{pH}=6.5$, and containing $1.2 \%$ methanol. The flow rate was $1 \mathrm{ml} / \mathrm{min}$ and the nucleotides detected at $254 \mathrm{~nm}$ (Cardoso et al. 2003; Monteiro et al. 2005).

\section{Determination of active ANT content}

Mitochondria $(0.5 \mathrm{mg})$ were incubated in $1 \mathrm{ml}$ of standard reaction medium $\left(200 \mathrm{mM}\right.$ sucrose, $5 \mathrm{mM} \mathrm{KH}_{2} \mathrm{PO}$, $20 \mathrm{mM}$ Tris- $\mathrm{HCl}, \mathrm{pH}$ 7.4). The reaction was performed at $30{ }^{\circ} \mathrm{C}$ in a closed chamber fitted with a Clark-type oxygen electrode (YSI model 5331, Yellow Spring Inst.). The active ANT content (ANT activity) was determined by titrating the rate of state 3 respiration with increasing concentrations of carboxyatractyloside (CAT) (Vignais 1976). Mitochondria were incubated in the absence or presence of isotretinoin and 2 min later CAT was added to mitochondria. After the incubation period $(1 \mathrm{~min})$, the reactions were started by the addition of $5 \mathrm{mM}$ glutamate $/ 2.5 \mathrm{mM}$ malate and state 3 respiration was initiated by adding $0.1 \mathrm{mM}$ ADP. Plots of $\mathrm{O}_{2}$ consumption versus CAT concentration are biphasic, with an increasing inhibitory effect followed by a steady-state effect which corresponds to the complete inhibition of state 3 respiration. The amount of CAT corresponding to complete inhibition of state 3 respiration was used to estimate ANT content assuming a 1:1 binding stoichiometry (Rousseau et al. 2003; Zhou et al. a

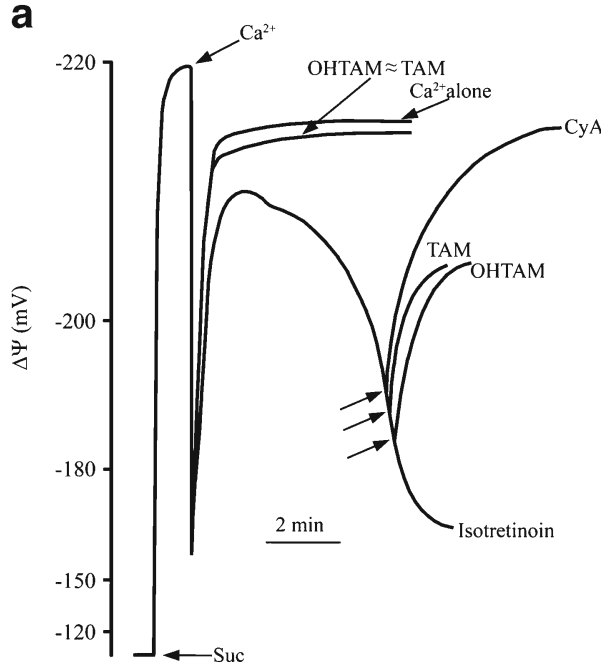

Fig. 1 Effect of isotretinoin alone or in combination with antiestrogenic compounds, TAM or OHTAM (a), adenosine nucleotide translocator (ANT) ligands, ADP or ATP, thiol protecting and antioxidants agents (b) on mitochondrial permeability transition (MPT) evaluated by the dissipation of mitochondrial transmembrane potential $(\Delta \psi)$. Additions of $5 \mathrm{mM}$ succinate (Suc), $120 \mathrm{nmol} \mathrm{Ca}{ }^{2+} / \mathrm{mg}$ protein $\left(\mathrm{Ca}^{2+}\right), 1 \mathrm{mM}$ dithiothreitol (DTT), $50 \mu \mathrm{M} N$-ethylmaleimide (NEM), $200 \mu \mathrm{M}$ cysteine

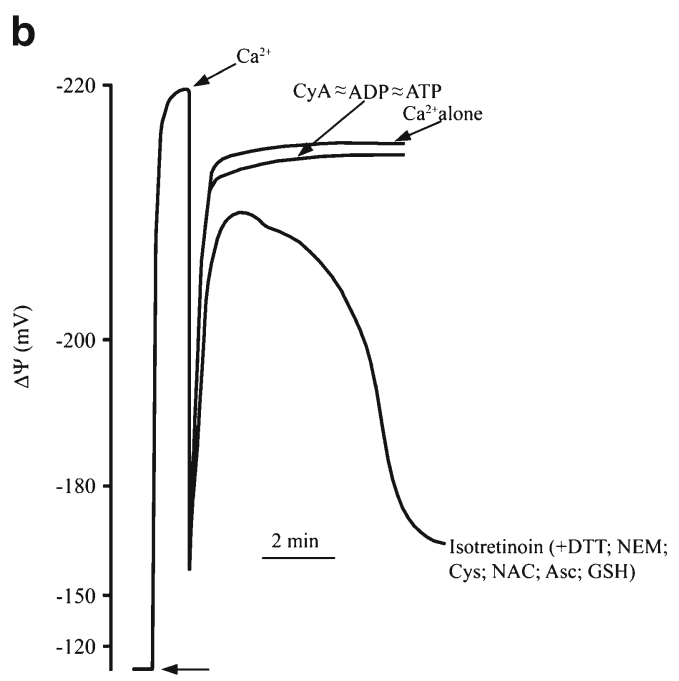

(Cys), $200 \mu \mathrm{M} \mathrm{N}$-acetylcysteine (NAC), $1 \mathrm{mM}$ ascorbic acid (Asc), $1 \mathrm{mM}$ glutathione (GSH), $75 \mu \mathrm{M}$ ADP (ADP), $150 \mu \mathrm{M}$ ATP (ATP), $1 \mu \mathrm{M}$ cyclosporine A (CyA), $10 \mathrm{nmol} \mathrm{TAM} / \mathrm{mg}$ protein, $10 \mathrm{nmol}$ $\mathrm{OHTAM} / \mathrm{mg}$ protein, before or after energization of mitochondria were performed as indicated. The traces are representative of four experiments with different mitochondrial preparations 
2001). The active ANT content was expressed as CAT amount per mg of mitochondrial protein (pmol CAT/mg protein) (Cardoso et al. 2003; Oliveira \& Wallace 2006).

\section{Statistical analysis}

The results are expressed as the mean $\pm \mathrm{SE}$ of four independent experiments and data were analysed using one-way ANOVA analysis of variance with Tukey multiple comparison test. A $p$-value $<0.05$ was considered statistically significant.

\section{Results}

Effect of antiestrogenic compounds on MPT pore opening induced by isotretinoin

The Fig. 1a presents the effects of isotretinoin alone or in combination with TAM or OHTAM on $\mathrm{Ca}^{2+}$-dependent MPT evaluated by the dissipation of $\Delta \psi$. In the absence of isotretinoin, the addition of $\mathrm{Ca}^{2+}(120 \mathrm{nmol} / \mathrm{mg}$ protein) to succinateenergized mitochondria caused a transient depolarization of $\Delta \psi$ followed by fast repolarization after $\mathrm{Ca}^{2+}$ accumulation, showing capacity to sustain $\Delta \psi$ (Fig. $1 \mathrm{a}-\mathrm{Ca}^{2+}$ alone). In contrast, the addition of $200 \mathrm{nmol} \mathrm{Ca}{ }^{2+} / \mathrm{mg}$ protein caused an irreversible depolarization of $\Delta \psi$ after $\mathrm{Ca}^{2+}$ addition (results not shown). The pre-incubation of mitochondria with isotretinoin $(5 \mathrm{nmol} / \mathrm{mg}$ protein or $2.5 \mu \mathrm{M})$ caused an irreversible depolarization of $\Delta \psi$ after addition of $120 \mathrm{nmol} \mathrm{Ca}{ }^{2+} / \mathrm{mg}$ protein (Fig. 1a-isotretinoin). The $\Delta \psi$ dissipation induced by isotretinoin was completely inhibited by CyA (Fig. 1a-CyA), a specific MPT inhibitor (Broekemeier et al. 1989). The preincubation of mitochondria with $5 \mu \mathrm{M}$ TAM or $5 \mu \mathrm{M}$ OHTAM $(10 \mathrm{nmol} / \mathrm{mg}$ protein) afforded complete protection against the irreversible depolarization induced by isotretinoin (Fig. 1aTAM and OHTAM). Moreover, the addition of TAM or OHTAM during the depolarization of $\Delta \psi$ promoted by isotretinoin induced repolarization of $\Delta \psi$ in a similar way to CyA (Fig. 1a), indicating that these compounds have the ability to prevent and revert the MPT induced by isotretinoin.

TAM and OHTAM are potent inhibitors of MPT pore opening probably due to its antioxidants properties (Custodio et al. 1998; Cardoso et al. 2002b). Therefore, to clarify the biochemical mechanisms by which MPT pore opening is potentiated by isotretinoin, we evaluated the effects of thiol protecting and antioxidants agents that prevent the MPT pore opening induced by oxidative stress mechanisms. As shown in Fig. 1b, the pre-incubation of mitochondria with thiol protecting and antioxidants agents, namely DTT, NEM, Cys, NAC, Asc and GSH did not prevent the $\Delta \psi$ depolarization induced by isotretinoin, in contrast to that observed with TAM and OHTAM (Fig. 1a). However, ANT ligands, ADP or ATP added to the mitochondria prior to the pre-incubation with isotretinoin, inhibited the irreversible mitochondrial depolarization (Fig. 1b-ADP and ATP).

The effects of isotretinoin ( $5 \mathrm{nmol} / \mathrm{mg}$ protein) alone or in combination with TAM and OHTAM were also investigated on $\mathrm{Ca}^{2+}$-dependent MPT by monitoring mitochondrial $\mathrm{Ca}^{2+}$ fluxes with a $\mathrm{Ca}^{2+}$-electrode (Fig. 2). The energization of mitochondria with succinate induced an accumulation of $\mathrm{Ca}^{2+}$ (120 nmol/mg protein) and mitochondria sustained the accumulated $\mathrm{Ca}^{2+}$ (Fig. 2-Ca ${ }^{2+}$ alone). The incubation of mitochondria with isotretinoin ( $5 \mathrm{nmol} / \mathrm{mg}$ protein) in the presence of $120 \mathrm{nmol} \mathrm{Ca}^{2+} / \mathrm{mg}$ protein led to the release of the accumulated $\mathrm{Ca}^{2+}$ (Fig. 2-isotretinoin). As observed with the $\mathrm{TPP}^{+}$-sensitive electrode (Fig. 1), CyA prevented the isotretinoin effects on $\mathrm{Ca}^{2+}$ release (Fig. 2-CyA). Again, the addition of TAM or OHTAM before or after the MPT induction by isotretinoin afforded a complete protection against the release of the accumulated $\mathrm{Ca}^{2+}$ (Fig. 2-TAM, OHTAM). However, and similarly to what was observed with the $\mathrm{TPP}^{+}$-sensitive electrode (Fig. 1b), the addition of thiol protecting and antioxidant agents did not prevent the release of the accumulated $\mathrm{Ca}^{2+}$ by mitochondria. The addition of ADP, an ANT ligand, before isotretinoin and $\mathrm{Ca}^{2+}$ inhibited the release of $\mathrm{Ca}^{2+}$ (Fig. 2-ADP).

\section{Effect of isotretinoin on rat liver mitochondrial} bioenergetics

The effects of isotretinoin were evaluated on oxygen consumption and $\Delta \psi$ of rat liver mitochondria (Figs. 3, 4, 5 and 6).

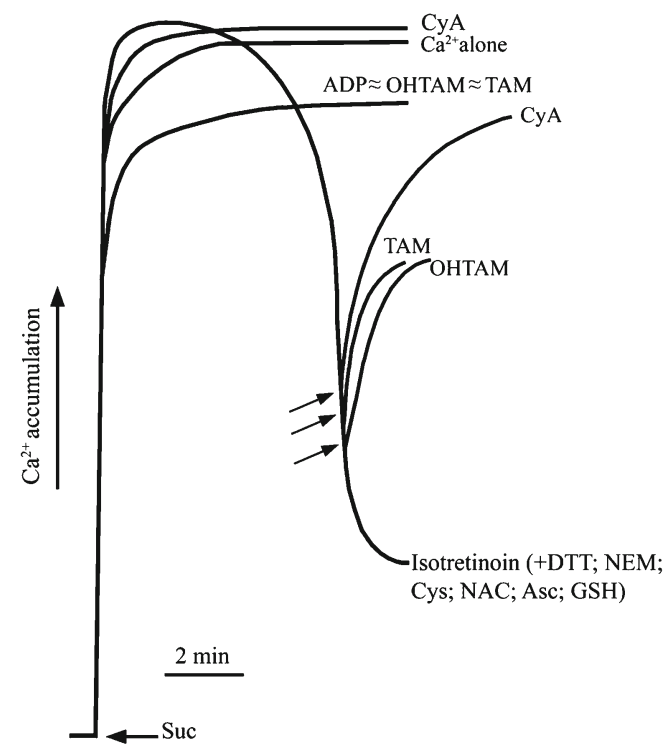

Fig. 2 Influence of antiestrogenic compounds (TAM or OHTAM) and ADP on isotretinoin-induced mitochondrial permeability transition (MPT) evaluated by mitochondrial $\mathrm{Ca}^{2+}$ fluxes. Additions of $5 \mathrm{mM}$ succinate (Suc), $120 \mathrm{nmol} \mathrm{Ca} \mathrm{Ca}^{2+} / \mathrm{mg}$ protein $\left(\mathrm{Ca}^{2+}\right), 75 \mu \mathrm{M}$ ADP (ADP), $1 \mu \mathrm{M}$ cyclosporine A (CyA), $10 \mathrm{nmol} \mathrm{TAM} / \mathrm{mg}$ protein, $10 \mathrm{nmol} \mathrm{OHTAM} / \mathrm{mg}$ protein, before or after energization of mitochondria were performed as indicated. The traces are representative of four independent assays with different mitochondrial preparations 

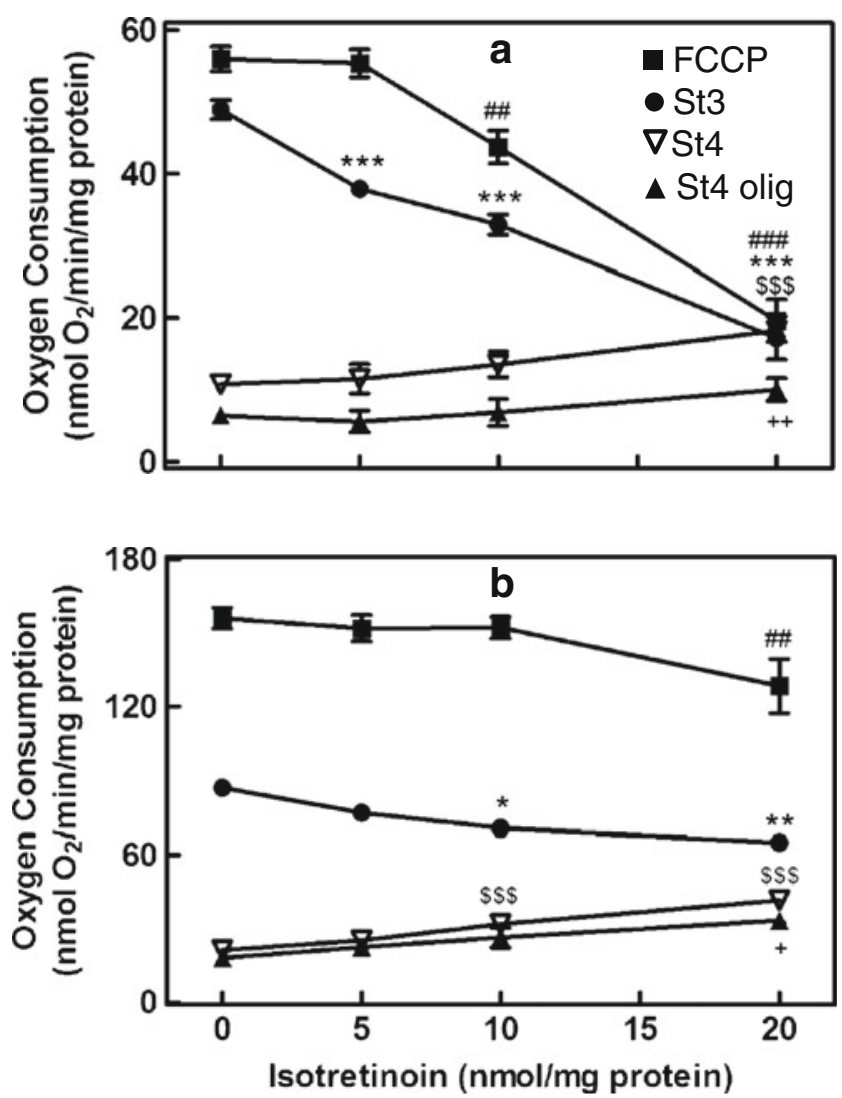

Fig. 3 Effect of isotretinoin on (a) glutamate/malate- and (b) succinate-supported respiration. $\mathrm{O}_{2}$ consumption rates of rat liver mitochondria in state 3 (closed circles), state 4 (open triangles), state 4 oligomycin (state 4 olig) (closed triangles) and FCCP-uncoupled respiration (closed squares). Results are presented as the mean $\pm \mathrm{SE}$ for the four experiments obtained from different mitochondrial preparations (when the error bars are not visible, SE is obscured by the size of the symbols). ${ }^{* * *} p<0.001, * * p<0.01$ and $* p<0.05$ when compared with the control (in the absence of isotretinoin) in state 3 respiration. ${ }^{\$ \$} \$<0.001 v s$ the respective control in state 4 respiration; ${ }^{\# \#} p<0.001$ and ${ }^{\# \#} p<0.01$ vs control in FCCP-uncoupled respiration. ${ }^{++} p<0.01$ and ${ }^{+} p<0.05$ when state 4 olig is compared with state 4 respiration

Isotretinoin pre-incubated with mitochondria energized with glutamate/malate significantly decreased the state 3 respiration in a concentration dependent way (Fig. 3a). At 5 and $10 \mathrm{nmol} / \mathrm{mg}$ protein $(5-10 \mu \mathrm{M})$ isotretinoin did not induce statistically significant alterations in the state 4 respiration, but $20 \mathrm{nmol}$ isotretinoin/mg protein significantly stimulated the state 4 respiration (Fig. 3a). The addition of ADP and oligomycin (state 4 oligomycin) to mitochondria pre-incubated with 5 and $10 \mathrm{nmol}$ isotretinoin $/ \mathrm{mg}$ protein induced a decrease in the state 4 oligomycin, though without statistical significance. At higher concentrations ( $\geq 20 \mathrm{nmol} / \mathrm{mg}$ protein), the addition of oligomycin decreased the oxygen consumption stimulated by isotretinoin (Fig. 3a). FCCP-uncoupled respiration was significantly decreased above $10 \mathrm{nmol}$ isotretinoin/mg protein (Fig. 3a). The effects of isotretinoin on the respiration rates, supported by succinate
(Fig. 3b), were slightly different from those observed with glutamate/malate (Fig. 3a). As presented in Fig. 3b, the state 4 respiration was significantly stimulated at concentrations above $10 \mathrm{nmol}$ isotretinoin/mg protein (Fig. 3a). State 3 was not significantly affected by $5 \mathrm{nmol}$ isotretinoin $/ \mathrm{mg}$ protein and at concentrations above $10 \mathrm{nmol}$ isotretinoin/mg protein the effects were less pronounced than in glutamate/malate supported respiration (Fig. 3b). Concerning FCCP-uncoupled respiration, we found that isotretinoin did not significantly affect this parameter at concentrations bellow $20 \mathrm{nmol}$ isotretinoin/mg protein in mitochondria energized with succinate (Fig. 3b). Moreover, at concentrations of $20 \mathrm{nmol}$ isotretinoin/mg protein the FCCP-uncoupled respiration was less affected (Fig. 3b), as compared with energization with glutamate/malate (Fig. 3a).

In mitochondria energized with glutamate/malate (Fig. 4a) the RCR and ADP/O indices were also slightly different from those observed with succinate (Fig. 4b). The addition of $5 \mathrm{nmol}$ isotretinoin/mg protein to mitochondria energized with glutamate/malate induced a significant decrease in RCR (Fig. 4). In the presence of higher concentrations of isotretinoin
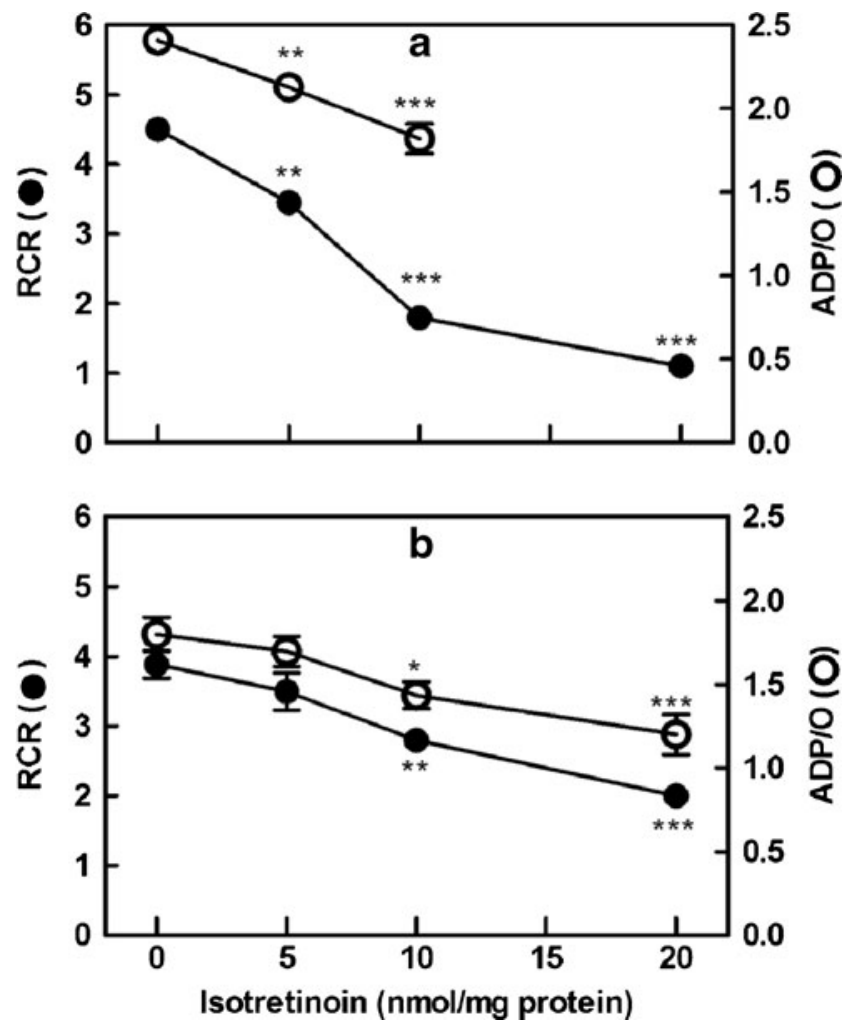

Fig. 4 Effect of isotretinoin on (a) glutamate/malate- and (b) succinate-supported respiration indices: respiratory control ratio (RCR) (closed circles) and ADP/O (open circles). Results are presented as the mean $\pm \mathrm{SE}$ of four experiments obtained from different mitochondrial preparations (when the error bars are not visible, SE is encompassed by the size of the symbols). ${ }^{* * *} p<0.001,{ }^{* *} p<0.01$ and $* p<0.05$ when compared with the respective control (in the absence of isotretinoin) 
( $>10 \mathrm{nmol} / \mathrm{mg}$ protein) this decrease was much more pronounced, as compared to control conditions (Fig. 4a), mainly due to the decrease in state 3 respiration. At concentrations of isotretinoin above $20 \mathrm{nmol} / \mathrm{mg}$ protein, the RCR ratio approaches 1.0 (Fig. 4a), suggesting that the phosphorylation of ADP did not occur due to an uncoupling effect on mitochondrial respiration. The $\mathrm{ADP} / \mathrm{O}$ index was also decreased and for $20 \mathrm{nmol}$ isotretinoin/mg protein we were not able to determine the $\mathrm{ADP} / \mathrm{O}$ ratio, because mitochondria were uncoupled, as shown by the RCR index (Fig. 4a). In mitochondria energized with succinate (Fig. 4b), the RCR was not significantly affected by $5 \mathrm{nmol}$ isotretinoin/mg protein and it was less decreased at concentrations of $10 \mathrm{nmol}$ isotretinoin/mg protein (Fig. 4b). However, this decrease is mainly a consequence of the stimulation of state 4 (Fig. 3b), since the state 3 respiration was less diminished when compared with mitochondria energized with glutamate/malate. Additionally, the RCR approaches a value of 2.0 for concentrations above $20 \mathrm{nmol}$ isotretinoin/mg protein (Fig. 4b), meaning that mitochondria are not completed uncoupled, as observed with glutamate/malate (Fig. 4a). Relatively to the $\mathrm{ADP} / \mathrm{O}$, we found that this index was also decreased at concentrations above $10 \mathrm{nmol}$ isotretinoin/mg protein (Fig. 4b), but the phosphorylative capacity of hepatic mitochondria in the presence of succinate was less affected than in mitochondria energized with glutamate/malate (Fig. 4a).

The depressive effect of isotretinoin on the phosphorylation capacity of mitochondria was further evaluated by following the $\Delta \psi$ fluctuations associated with the phosphorylation cycle induced by ADP (Figs. 5 and 6). After the addition of glutamate/malate (Fig. 5), in the absence of isotretinoin, mitochondria developed a $\Delta \psi$ of about $219.9 \pm 1.3 \mathrm{mV}$ (negative inside). The addition of isotretinoin at concentrations of 5 and $10 \mathrm{nmol} / \mathrm{mg}$ protein did not significantly affect the mitochondrial $\Delta \psi$. However, at $20 \mathrm{nmol}$ isotretinoin/mg protein, we found a significant decrease in the $\Delta \psi$ (Fig. 5). The addition of ADP in the absence of isotretinoin dropped the $\Delta \psi$ in $25.1 \pm 1.6 \mathrm{mV}$ (ADP depolarization). The preincubation with isotretinoin at concentrations above $10 \mathrm{nmol} / \mathrm{mg}$ protein decreased the ADP depolarization (Fig. 5). The time required for the phosphorylation of $\mathrm{ADP}$ (lag phase) in the absence of isotretinoin was $63.4 \pm 1.7 \mathrm{~s}$, while the addition of 5 and $10 \mathrm{nmol}$ isotretinoin/mg protein induced a significant increase (Fig. 5). At $20 \mathrm{nmol}$ isotretinoin/mg protein the lag phase was not measured since the phosphorylation of ADP did not occur in agreement with the RCR index (Fig. 4a). When ADP phosphorylation occurred, the repolarization and
Fig. 5 Effect of isotretinoin on glutamate/malate-dependent transmembrane potential $(\Delta \psi)$ of rat liver mitochondria. The traces represent typical records from experiments performed in the conditions described in "Material and Methods". The arrows indicate the additions of $5 \mathrm{mM}$ glutamate $/ 2.5 \mathrm{mM}$ malate (Glu/Mal), $150 \mathrm{nmol}$ $\mathrm{ADP} / \mathrm{mg}$ protein (ADP), and the numbers on the right to the traces are the concentrations of isotretinoin. Data in the table below, present the mean \pm SE of four experiments obtained from different mitochondrial preparations. $* * * p<0.001$, $* * p<0.01$ and $* p<0.05$ vs control (in the absence of isotretinoin)

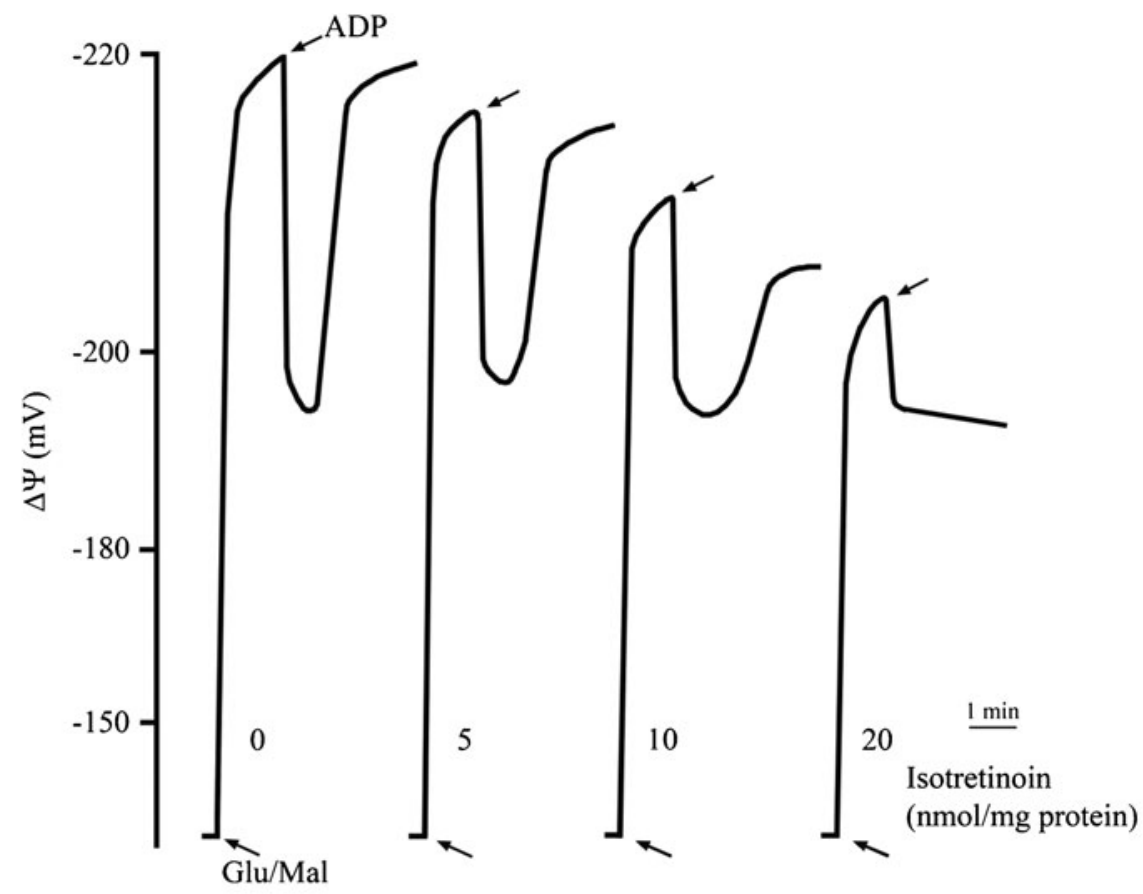

\begin{tabular}{ccccc}
\hline \multirow{2}{*}{$\begin{array}{c}\text { Isotretinoin } \\
\text { (nmol/mg protein) }\end{array}$} & $\begin{array}{c}\text { Glu/Mal } \\
\text { Energization }\end{array}$ & $\begin{array}{c}\Delta \mathbf{A D P}(-\mathbf{m V}) \\
\text { depolarization }\end{array}$ & Repolarization & Lag Phase (s) \\
\hline $\mathbf{0}$ & $219.9 \pm 1.3$ & $25.1 \pm 1.6$ & $219.6 \pm 1.0$ & $63.4 \pm 1.7$ \\
$\mathbf{5}$ & $217,8 \pm 2.0$ & $23.1 \pm 1.1$ & $216.1 \pm 1.8$ & $80.0 \pm 2.6^{* * *}$ \\
$\mathbf{1 0}$ & $212.4 \pm 3.6$ & $20.6 \pm 1.6^{*}$ & $206.6 \pm 3.4$ & $98.0 \pm 3.6^{* * * *}$ \\
$\mathbf{2 0}$ & $202.4 \pm 4.1^{* * * *}$ & $12.8 \pm 0.7^{* * *}$ & nd & nd \\
\hline
\end{tabular}


Fig. 6 Effect of isotretinoin on succinate-dependent transmembrane potential $(\Delta \psi)$ of rat liver mitochondria. The traces represent typical records from experiments performed in the conditions described in "Material and Methods". The arrows indicate the additions of $5 \mathrm{mM}$ succinate $(\mathrm{Suc})$, $150 \mathrm{nmol} \mathrm{ADP} / \mathrm{mg}$ protein (ADP), and the numbers on the right of the traces are the concentrations of isotretinoin. Data in the table below, present the mean $\pm \mathrm{SE}$ of the transmembrane potential at the different concentrations of isotretinoin. $* * * p<0.001$ and ${ }^{*} p<0.05 v s$ control (in the absence of isotretinoin)

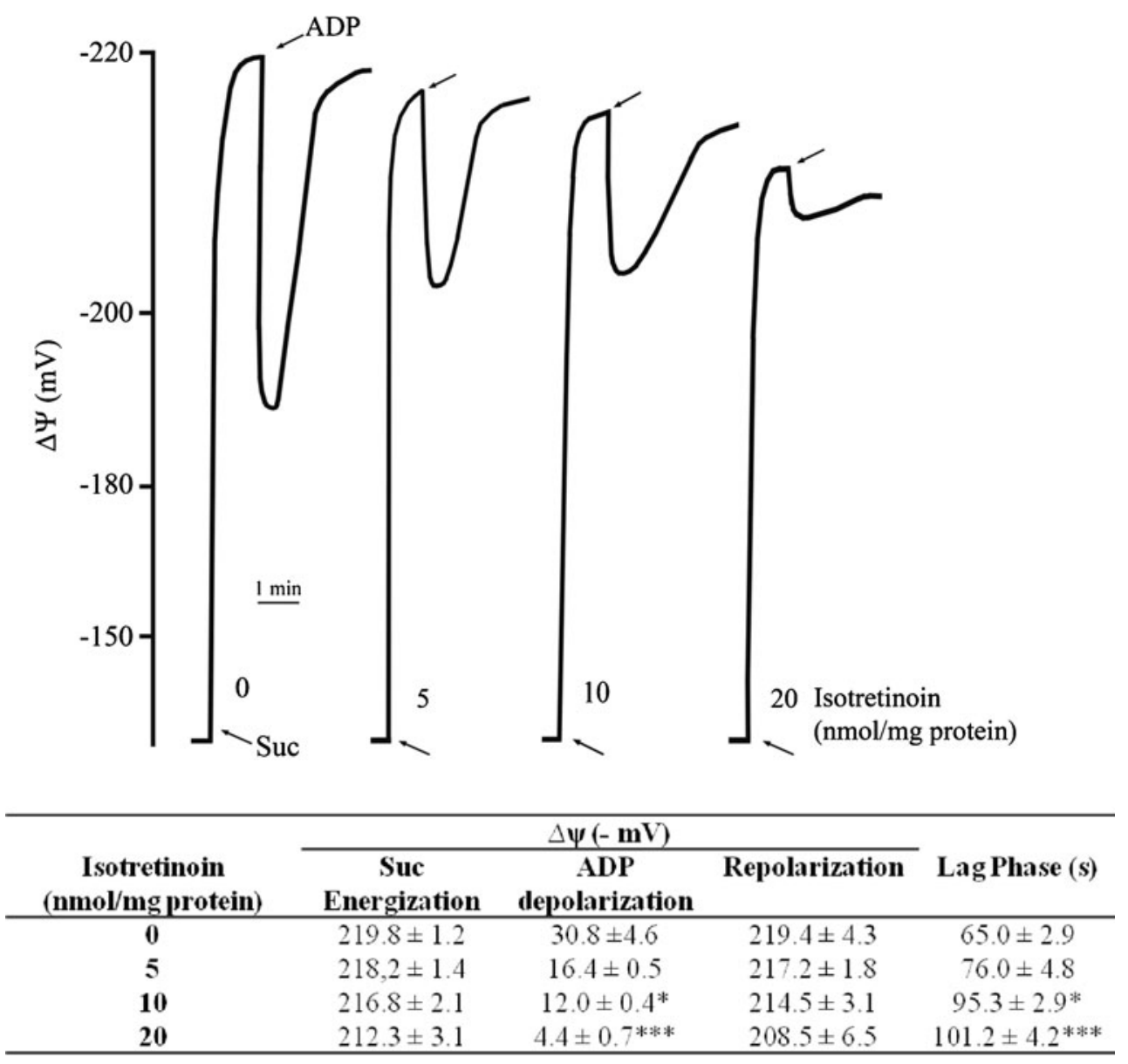

the transmembrane potential returned to the initial value $(-219.6 \pm 1.0 \mathrm{mV})$. In the presence of 5 and $10 \mathrm{nmol} / \mathrm{mg}$ protein, isotretinoin did not change the potential repolarization. At concentrations above $20 \mathrm{nmol}$ isotretinoin/mg protein the repolarization did not occur and mitochondria had no capacity to sustain the $\Delta \psi$ (Fig. 5).

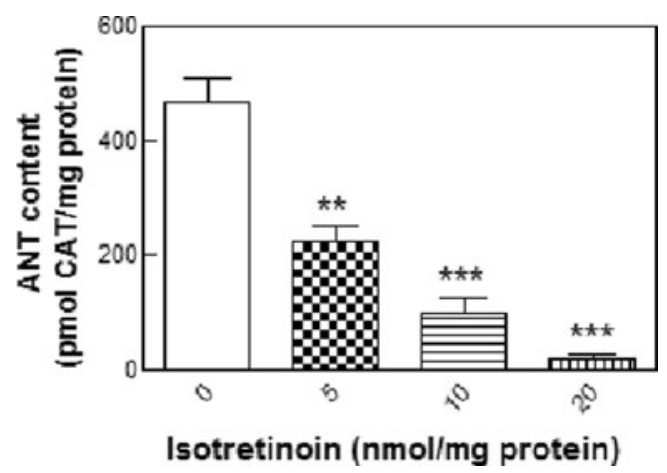

Fig. 7 Effect of isotretinoin on mitochondrial active adenine nucleotide translocase (ANT) content. The experiments were performed out as described in "Material and Methods" and data are expressed as pmol carboxyatractyloside (CAT) per $\mathrm{mg}$ of mitochondrial protein. The values are present as the mean $\pm \mathrm{SE}$ of four different experiments, using different mitochondrial preparations. $* * * p<0.001$ and $* * p<0.01$ $v s$ control (in the absence of isotretinoin)
In mitochondria energized with succinate (Fig. 6), the results were slightly different, when compared with those observed with glutamate/malate (Fig. 5). In fact, the lag phase of phosphorylation cycle was only significantly affected at concentrations above $10 \mathrm{nmol}$ isotretinoin/mg protein in mitochondria energized with succinate (Fig. 6), while $5 \mathrm{nmol}$ isotretinoin/mg protein decreased the lag phase in mitochondria energized with glutamate/malate (Fig. 5). On the contrary, in mitochondria energized with glutamate/malate, the $\Delta \psi$ developed after the addition of $20 \mathrm{nmol}$ isotretinoin/mg protein was not affected (Fig. 6). Furthermore, at $30 \mathrm{nmol}$ isotretinoin/mg protein, mitochondria energized with succinate had the capacity to maintain the $\Delta \psi$ after the addition of ADP (data not shown), in contrast to that observed in mitochondria pre-incubated with $20 \mathrm{nmol}$ isotretinoin/mg protein and energized with glutamate/malate.

\section{Effect of isotretinoin on the active ANT content}

The active ANT content (ANT activity) was also determined to clarify the MPT pore opening and the changes in the mitochondrial phosphorylation induced by isotretinoin (Fig. 7). The mitochondrial content of active ANT was determined by the amount of CAT required to reduce state 3 respiration to the 
state 4 respiration rate, when CAT saturates the translocase sites (Vignais 1976). In the absence of isotretinoin, the ANT was only inhibited by the addition of $468 \mathrm{pmol}$ CAT/mg protein. However, in the presence of 5 and $10 \mathrm{nmol}$ isotretinoin/mg the active ANT content was decreased to about 222 and $97 \mathrm{pmol} \mathrm{CAT/mg} \mathrm{protein,} \mathrm{respectively} \mathrm{(Fig.} \mathrm{7),} \mathrm{which}$ corresponds to approximately $47 \%$ and $21 \%$ of the control. At $20 \mathrm{nmol} / \mathrm{mg}$ protein, isotretinoin inhibited almost completely
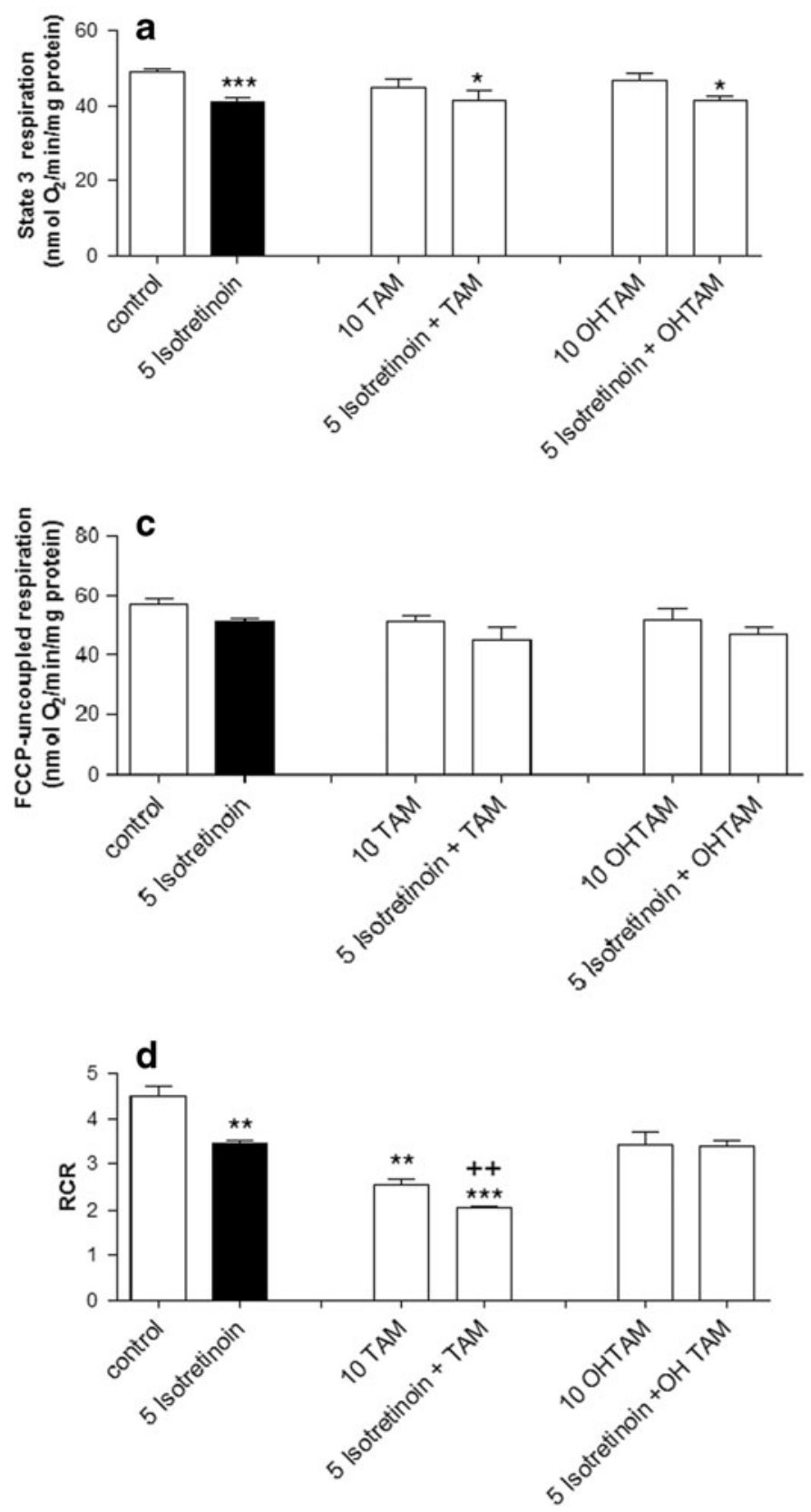

Fig. 8 Effect of isotretinoin alone (5 $\mathrm{nmol} / \mathrm{mg}$ protein) or in combination with antiestrogenic compounds $(10 \mathrm{nmol} / \mathrm{mg}$ protein) on glutamate/malate- supported respiration. The rates of $\mathrm{O}_{2}$ consumption (a) in state 3, (b) state 4 and state 4 oligomycin (state 4 olig), (c) FCCP-uncoupled respiration, and the respiration indices, (d) respiratory control ratio (RCR) and the active ANT content, suggesting that isotretinoin interferes with the ANT in a concentration dependent way.

Effect of isotretinoin combined with antiestrogens on mitochondrial phosphorylation efficiency

Besides the inhibition of isotretinoin-induced MPT (Figs. 1 and 2), the effects of isotretinoin in combination with OHTAM
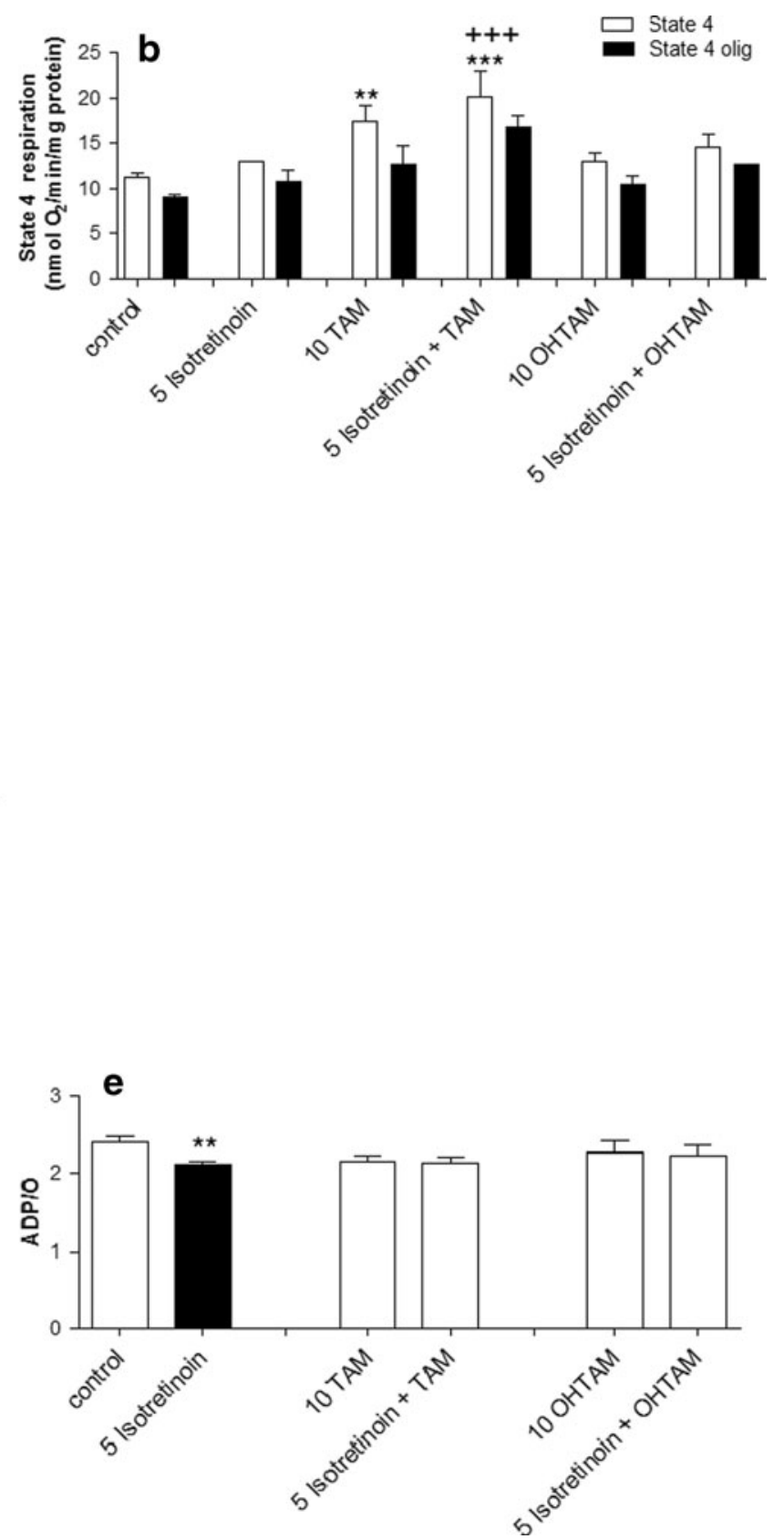

(e) ADP/O of rat liver mitochondria, are shown. Results are presented as the mean $\pm \mathrm{SE}$ of four experiments using from different mitochondrial preparations. ${ }^{* *} p<0.001,{ }^{* *} p<0.01$ and $* p<0.05$ when compared with the control (in the absence of isotretinoin) conditions. ${ }^{++} p<0.001,{ }^{++} p<$ 0.01 when compared with isotretinoin alone 
or TAM were also evaluated on respiratory chain (Fig. 8) and on the energetic levels (Table 1) of mitochondria.

The combination of $5 \mathrm{nmol}$ isotretinoin $/ \mathrm{mg}$ protein $(5 \mu \mathrm{M})$ with OHTAM or TAM $(10 \mathrm{nmol} / \mathrm{mg}$ protein or $10 \mu \mathrm{M})$ induced a significant decrease in state 3 respiration (Fig. 8a). However, this decrease was not statistically significant when compared with isotretinoin alone $(5 \mathrm{nmol} / \mathrm{mg}$ protein) that was able to induce a decrease in state 3 . The state 4 respiration was not significantly stimulated when isotretinoin was combined with OHTAM (Fig. 8b). On the contrary, isotretinoin in combination with TAM induced a significant increase in state 4 respiration, as compared to the control and isotretinoin alone. The fact that the addition of oligomycin did not decrease the oxygen consumption stimulated by TAM combined with isotretinoin (Fig. 8b) suggests that the state 4 stimulation induced by this association is not due to proton leak through Fo fraction of complex $\mathrm{V}$ of the respiratory chain. By monitoring the changes in the FCCP-uncoupled respiration (Fig. 8c), we found that the studied associations did not inhibit the respiratory chain activity. In agreement with the results obtained for state 3 and state 4 respiration, the combination of isotretinoin with OHTAM did not decrease significantly the RCR ratio (Fig. 8d). However, the combination of isotretinoin with TAM induced a significant decrease in the RCR value (Fig. 8d), as a consequence of the stimulation of state 4 respiration (Fig. 8b). The ADP/O ratio was not changed by the combination of isotretinoin with OHTAM or TAM (Fig. 8e).

The effects of isotretinoin alone or in combination with either TAM or OHTAM on the mitochondrial energetic levels were also determined by evaluating the ATP and ADP contents by HPLC (Table 1). The addition of $5 \mathrm{nmol}$ isotretinoin $/ \mathrm{mg}$ protein $(5 \mu \mathrm{M})$ induced a significant decrease in the ATP levels, while the ADP levels increased. These effects were more pronounced in the presence of higher concentrations of isotretinoin ( $\geq 10 \mathrm{nmol} / \mathrm{mg}$ protein) (Table 1), suggesting that phosphorylation is compromised, according to the RCR index (Fig. 54a) and to the phosphorylation cycle (Figs. 3a and 5). Interestingly, the co-incubation of mitochondria with isotretinoin $(5 \mathrm{nmol} / \mathrm{mg}$ protein) and TAM or OHTAM (10 nmol/mg protein) did not induce significant changes in the ATP and ADP levels (Table 1), and the values were similar to those observed in the presence of both antiestrogens individually (data not shown), as previously reported (Cardoso et al. 2003).

\section{Discussion}

This study demonstrates that isotretinoin is an effective inducer of the $\mathrm{Ca}^{2+}$-dependent MPT pore opening (Figs. 1 and 2), in agreement with Rigobello et al. (1999). In our experimental conditions, isotretinoin promoted MPT pore opening at $5 \mathrm{nmol} / \mathrm{mg}$ protein $(2.5 \mu \mathrm{M})$, which is lower than the concentration used by Rigobello et al. (1999) (4 to $33 \mu \mathrm{M}$ or 16 to $132 \mathrm{nmol} / \mathrm{mg}$ protein). Isotretinoin at $5 \mathrm{nmol} / \mathrm{mg}$ protein did not affect the respiratory chain (Figs. 3 and 4), and did not alter the $\Delta \psi$ developed by mitochondria (Figs. 5 and 6). Moreover, the depolarization of $\Delta \psi$ and the release of $\mathrm{Ca}^{2+}$ associated to MPT induction by $5 \mathrm{nmol}$ isotretinoin $/ \mathrm{mg}$ protein were reverted by the addition of CyA after the pore opening (Figs. 1 and 2), suggesting that isotretinoin is directly affecting the conformational structure of the constituents of the mega protein complex comprising the MPT pore. Isotretinoin changed significantly the mitochondrial respiration and the oxidative phosphorylation only at concentrations higher than $5 \mathrm{nmol} / \mathrm{mg}$ protein (Figs. 3, 4, 5 and 6) (Table 1). The modulation of the MPT has been associated with the orientation of the ADP/ATP translocase across the inner membrane. Our data strengthens this hypothesis, as we found that isotretinoin at concentrations higher than $5 \mu \mathrm{M}$ strongly alters the active ANT content (ANT activity) (Fig. 7).

Our study demonstrated that the isotretinoin-induced $\mathrm{Ca}^{2+}$ dependent $\Delta \psi$ depolarization (Fig. 1) and $\mathrm{Ca}^{2+}$ release (Fig. 2), due to MPT promotion, were prevented and reverted by TAM and OHTAM, suggesting that both antiestrogens are inhibitors of the MPT pore opening induced by isotretinoin. It has been documented that the MPT induction may occur following an

Table 1 Effect of isotretinoin alone or combined with TAM or OHTAM on the levels of ATP and ADP in liver mitochondria respiring glutamate/ malate. Data correspond to the mean \pm SEM of four independent experiments with different mitochondrial preparations

\begin{tabular}{llll}
\hline $\begin{array}{l}\text { Isotretinoin } \\
\text { (nmol/mg protien) }\end{array}$ & $\begin{array}{l}\text { TAM/OHTAM } \\
(\mathrm{nmol} / \mathrm{mg} \text { protien) }\end{array}$ & $\begin{array}{l}\text { ADP } \\
\text { (nmol/mg protien) }\end{array}$ & $\begin{array}{l}\text { ATP } \\
(\mathrm{nmol} / \mathrm{mg} \text { protien) }\end{array}$ \\
\hline 0 & - & $9.3 \pm 2.2$ & $126.3 \pm 8.3$ \\
5 & - & $16.6 \pm 1.4^{* *}$ & $102.2 \pm 1.7^{* *}$ \\
10 & - & $334 . \pm 3.6^{* * *}$ & $72.7 \pm 1.7^{* * *}$ \\
20 & - & $51.6 \pm 3.2^{* * *}$ & $40.3 \pm 10.9 * * *$ \\
5 & - & & $12.8 \pm 3.4$ \\
5 & 10 TAM & $12.8 \pm 3.4$ & $119.6 \pm 8.1$ \\
\hline
\end{tabular}

$* * * p<0.001$ and $* * p<0.01$ when compared with the respective control (in the absence of isotretinoin). 
oxidative stress event (Halestrap et al. 1997). In opposition to TAM and OHTAM, known as intramembranous antioxidants (Custodio et al. 1994), the addition of thiol protecting and antioxidant agents (DTT, NEM, Cys, NAC, Asc and GSH) did not prevent the MPT pore opening induced by isotretinoin (Figs. 1b and 2). Thus, the use of these compounds that are effective inhibitors of permeability transition, demonstrates that isotretinoin-induced MPT cannot be related to oxidative alterations of the mitochondrial proteins of the MPT pore. ANT ligands, such as ATP and ADP, prevented the MPT pore opening induced by isotretinoin (Figs. $1 \mathrm{~b}$ and 2 ). Both adenine nucleotides inhibited pore opening by binding to both highand low-affinity sites of the ANT, preventing calcium from inducing the cyclophilin-D-mediated conformational change (Halestrap \& Pasdois 2009). Isotretinoin can induce the MPT through an interaction with the mitochondrial cyclophilin-D and the adenine nucleotide translocator, which is in accordance with the effects obtained by titration of mitochondria with carboxyatractyloside (Fig. 7). Noteworthy, photoaffinity labeling studies have demonstrated that tretinoin (all-trans-retinoic acid) directly binds to the ANT (Notario et al. 2003). We may, therefore, propose that as occurs with carboxyatractyloside, isotretinoin can promote pore opening by stabilizing ANT in the cytosolic side of the inner membrane. Our hypothesis seems to be in agreement with the inhibition of the MPT by TAM and OHTAM. As the antiestrogens do not significantly affect the active ANT content at the concentrations used to inhibit isotretinoin-induced MPT (Cardoso et al. 2003), it is plausible that the antiestrogens, which strongly partition in the core of biomembranes (Custodio et al. 1991), prevent the MPT induced by isotretinoin through the decrease of membrane fluidity (Custodio et al. 1993; Kazanci \& Severcan 2007). This effect would indirectly compromise the activity of membrane proteins, such as the ANT. These multiple mechanisms of antiestrogens may prevent the conformational changes promoted by isotretinoin, which are involved in the MPT induction.

Isotretinoin-induced changes observed in mitochondrial functions and in different cancer cell lines (Arce et al. 2005; Guruvayoorappan et al. 2008; Vuletic et al. 2010) were also observed with other drugs (Kass 2006) and may explain some side effects described in patients treated with isotretinoin (Goodfield et al. 2010; Sardana \& Garg 2011). Thus, the association of TAM or OHTAM with isotretinoin therapy may be crucial to reduce or avoid the adverse effects observed in monotherapy with isotretinoin. Moreover, the interaction of isotretinoin with the ANT, a regulatory element of the MPT pore (Pebay-Peyroula \& Brandolin 2004; Zorov et al. 2009), suggests a possible mechanism for MPT pore induction and may also explain the decrease in state 3 respiration (Fig. 3a) since, as reported above, isotretinoin at $5 \mathrm{nmol} / \mathrm{mg}$ protein did not induce any other change responsible for this effect (Figs. 3, 4, 5 and 6).

Our study also showed that isotretinoin induced more significant changes in different mitochondrial functions at concentration above $10 \mathrm{nmol} / \mathrm{mg}$ protein. In fact, isotretinoin depressed the phosphorylation capacity of hepatic mitochondria, as shown by the decrease in state 3 respiration (Fig. 3a), RCR, ADP/O indices (Fig. 4a), ATP levels (Table 1) and by the increase in the lag phase of ADP phosphorylation cycle (Fig. 5). Nevertheless, isotretinoin at this concentration slightly affected the respiratory chain, as suggested by its effect on FCCP-uncoupled respiration (Fig. 3a), and in the membrane potential developed by mitochondria (Fig. 5). However, the results demonstrated that isotretinoin significantly decreased the ANT content (Fig. 7), indicating that the interaction with this component of the phosphorylation system, may be the main factor involved in the decrease of mitochondrial phosphorylative efficiency induced by isotretinoin. At higher concentrations ( $\geq 10 \mathrm{nmol} / \mathrm{mg}$ protein) isotretinoin significantly potentiated the mitochondrial dysfunctions described above and uncoupled the mitochondrial respiration as inferred from the decrease in the respiratory control ratio (Fig. 3a), ADP/O index (Fig. 4a) and from the effects on the ADP phosphorylation cycle (Fig. 5). This effect is probably due to the strong changes induced in the active ANT content (Fig. 7) and to its ability to affect the conformational structure of complex $\mathrm{V}$ proteins, namely the fraction Fo of ATP synthase, inducing leak of protons as evidenced by the effects on state 4 oligomycin (Fig. 3a) and by the decrease in $\Delta \psi$ (Fig 5). The inhibitory effect on the respiratory chain complex I is inferred from the significant decrease in the FCCP-uncoupled respiration (Fig. 3a) and the $\Delta \psi$ developed by mitochondria energized with glutamate/malate (Fig. 5), as compared with the slight changes induced in mitochondria energized with succinate (Figs. 3b and 6). This inhibitory effect on respiratory complex I also contributes to the impairment of mitochondria promoted by high concentrations of isotretinoin. It is possible that these mitochondrial dysfunctions may underlie or contribute to the numerous side effects observed in patients treated with high isotretinoin concentrations (Goodfield et al. 2010; Sardana \& Garg 2011). Thus, the combination of isotretinoin with other compounds would be an important therapeutic approach, by promoting an additive/synergistic therapeutic action and an important improvement in patient's quality of life, as the use of lower concentrations of each compound would lead to a reduction in the adverse side effects.

When we combined low concentrations of isotretinoin (5 nmol/mg protein) with TAM or OHTAM $(10 \mathrm{nmol} / \mathrm{mg}$ protein), besides the protective effect observed in the MPT pore opening, no significant changes were observed in the oxidative phosphorylation system and in the respiratory chain (Fig. 8), as compared with isotretinoin alone. An exception was observed when isotretinoin was combined with TAM, occurring a stimulation of the state 4 that is possibly due to the permeabilization of the inner mitochondrial membrane to protons, induced by TAM, as previously described by Cardoso et al. (2001). Moreover, TAM and 
OHTAM, which at the concentrations tested did not change the mitochondria phosphorylation efficiency (Cardoso et al. 2003), promoted a reduction in the ATP depletion induced by isotretinoin (Table 1). The prevention of isotretinoininduced MPT by both antiestrogens (Figs. 1 and 2), may rely on the fact that TAM and OHTAM lock the ANT on the mitochondrial membrane, diminishing the interaction of isotretinoin with the adenine nucleotide carrier or competing for the binding sites of isotretinoin in the ANT.

Our data show that isotretinoin induces different dysfunctional changes in mitochondria. These mitochondrial dysfunctions include an increase in the sensitivity of mitochondria to $\mathrm{Ca}^{2+}$-induced MPT, which is prevented by TAM and OHTAM, and bioenergetic damaging effects. Mitochondrial dysfunction is a triggering event for cell toxicity and death, due to their crucial role in cell homeostasis. Our studies in mitochondria suggest that isotretinoin-associated liver toxicity and apoptosis is possibly related with mitochondrial dysfunctions due to interactions with the ANT. The abnormalities in liver functions and systemic side effects observed in patients treated with this retinoid (Erturan et al. 2012) may be related with the mitochondrial damage described since the concentrations of isotretinoin used in our experiments $(5-10 \mathrm{nmol} / \mathrm{mg}$ protein or $5-10 \mu \mathrm{M})$ correspond to those that are usually achieved in blood with therapeutic doses of $160 \mathrm{mg} / \mathrm{m} 2 /$ day $(7.2 \pm 5.3 \mu \mathrm{M})$ (Erturan et al. 2012; Veal et al. 2007), although different studies indicated a $>10$-fold inter-patient variation in plasma concentrations. Plasma concentrations above $10 \mu \mathrm{M}$ were correlated with an increased incidence of hepatic toxicity, hyperkaliemia and hipercalcemia (Erturan et al. 2012). Therefore, we propose that the use of isotretinoin combined with OHTAM can reduce the side effects on proteins responsible for $\mathrm{Ca}^{2+}$ homeostasis and energy production in the cell. Further in vivo studies are required to clarify the toxicity and safety of the combination of isotretinoin with antiestrogens in humans, in order to establish the therapeutic efficacy of this therapy.

Acknowledgments This study was supported by $\mathrm{PhD}$ grant (SFRH/ BD/37686/2007) attributed to F.S.G. Silva by Fundação para a Ciência e Tecnologia.

\section{References}

Arce F, Gatjens-Boniche O, Vargas E, Valverde B, Diaz C (2005) Apoptotic events induced by naturally occurring retinoids ATRA and 13-cis retinoic acid on human hepatoma cell lines Hep3B and HepG2. Cancer Lett 229:271-281

Broekemeier KM, Dempsey ME, Pfeiffer DR (1989) Cyclosporin A is a potent inhibitor of the inner membrane permeability transition in liver mitochondria. J Biol Chem 264:7826-7830

Cardoso CM, Custodio JB, Almeida LM, Moreno AJ (2001) Mechanisms of the deleterious effects of tamoxifen on mitochondrial respiration rate and phosphorylation efficiency. Toxicol Appl Pharmacol 176:145-152
Cardoso CM, Moreno AJ, Almeida LM, Custodio JB (2002a) 4Hydroxytamoxifen induces slight uncoupling of mitochondrial oxidative phosphorylation system in relation to the deleterious effects of tamoxifen. Toxicology 179:221-232

Cardoso CM, Almeida LM, Custodio JB (2002b) 4-Hydroxytamoxifen is a potent inhibitor of the mitochondrial permeability transition. Mitochondrion 1:485-495

Cardoso CM, Moreno AJ, Almeida LM, Custodio JB (2003) Comparison of the changes in adenine nucleotides of rat liver mitochondria induced by tamoxifen and 4-hydroxytamoxifen. Toxicol In Vitro 17:663-670

Cardoso CM, Almeida LM, Custodio JB (2004) Protection of tamoxifen against oxidation of mitochondrial thiols and $\mathrm{NAD}(\mathrm{P}) \mathrm{H}$ underlying the permeability transition induced by prooxidants. Chem-Biol Interact 148:149-161

Chambon P (1996) A decade of molecular biology of retinoic acid receptors. FASEB J 10:940-954

Chance B, Williams GR (1956) Respiratory enzymes in oxidative phosphorylation. VI. The effects of adenosine diphosphate on azide-treated mitochondria. J Biol Chem 221:477-489

Cruz Silva MM, Madeira VM, Almeida LM, Custodio JB (2001) Hydroxytamoxifen interaction with human erythrocyte membrane and induction of permeabilization and subsequent hemolysis. Toxicol In Vitro 15:615-622

Custodio JB, Almeida LM, Madeira VM (1991) A reliable and rapid procedure to estimate drug partitioning in biomembranes. Biochem Biophys Res Commun 176:1079-1085

Custodio JB, Almeida LM, Madeira VM (1993) The anticancer drug tamoxifen induces changes in the physical properties of model and native membranes. Biochim Biophys Acta 1150:123-129

Custodio JB, Dinis TC, Almeida LM, Madeira VM (1994) Tamoxifen and hydroxytamoxifen as intramembraneous inhibitors of lipid peroxidation. Evidence for peroxyl radical scavenging activity. Biochem Pharmacol 47:1989-1998

Custodio JB, Moreno AJ, Wallace KB (1998) Tamoxifen inhibits induction of the mitochondrial permeability transition by $\mathrm{Ca} 2+$ and inorganic phosphate. Toxicol Appl Pharmacol 152:10-17

Custodio JB, Cardoso CM, Almeida LM (2002) Thiol protecting agents and antioxidants inhibit the mitochondrial permeability transition promoted by etoposide: Implications in the prevention of etoposideinduced apoptosis. Chem-Biol Interact 140:169-184

Czeczuga-Semeniuk E, Wolczynski S, Dzieciol J, Dabrowska M, Anchim T, Tomaszewska I (2001) 13-cis retinoic acid and all-trans retinoic acid in the regulation of the proliferation and survival of human breast cancer cell line MCF-7. Cell Mol Biol Lett 6:925-939

Damodaran SE, Pradhan SC, Umamaheswaran G, Kadambari D, Reddy KS, Adithan C (2012) Genetic polymorphisms of CYP2D6 increase the risk for recurrence of breast cancer in patients receiving tamoxifen as an adjuvant therapy. Cancer Chemother Pharmacol 70:75-81

Demirpence E, Balaguer P, Trousse F, Nicolas JC, Pons M, Gagne D (1994) Antiestrogenic effects of all-trans-retinoic acid and 1,25dihydroxyvitamin D3 in breast cancer cells occur at the estrogen response element level but through different molecular mechanisms. Cancer Res 54:1458-1464

Erturan I, Naziroglu M, Akkaya VB (2012) Isotretinoin treatment induces oxiative stress toxicity in blood of patients with acne vulgaris: A clinical study. Cell Biochem Funct 30:552-557

Fulda S, Galluzzi L, Kroemer G (2010) Targeting mitochondria for cancer therapy. Nat Rev Drug Discov 9:447-464

Gazotti P, Malmstron K, Crompton M (1979) Membrane biochemistry: a laboratory manual on transport and bioenergetics. Springer, New York

Goodfield MJ, Cox NH, Bowser A, McMillan JC, Millard LG, Simpson NB, Ormerod AD (2010) Advice on the safe introduction and continued use of isotretinoin in acne in the U.K. 2010. Br J Dermatol 162:1172-1179 
Gornall AG, Bardawill CJ, David MM (1949) Determination of serum proteins by means of the biuret reaction. J Biol Chem 177:751-766

Guruvayoorappan C, Pradeep CR, Kuttan G (2008) 13-cis-retinoic acid induces apoptosis by modulating caspase-3, bcl-2, and p53 gene expression and regulates the activation of transcription factors in B16F-10 melanoma cells. J Environ Pathol Toxicol Oncol 27:197-207

Halestrap AP, Pasdois P (2009) The role of the mitochondrial permeability transition pore in heart disease. Biochim Biophys Acta 1787:1402-1415

Halestrap AP, Woodfield KY, Connern CP (1997) Oxidative stress, thiol reagents, and membrane potential modulate the mitochondrial permeability transition by affecting nucleotide binding to the adenine nucleotide translocase. J Biol Chem 272:3346-3354

Hua S, Kittler R, White KP (2009) Genomic antagonism between retinoic acid and estrogen signaling in breast cancer. Cell 137:1259-1271

Kamo N, Muratsugu M, Hongoh R, Kobatake Y (1979) Membrane potential of mitochondria measured with an electrode sensitive to tetraphenyl phosphonium and relationship between proton electrochemical potential and phosphorylation potential in steady state. J Membr Biol 49:105-121

Kass GE (2006) Mitochondrial involvement in drug-induced hepatic injury. Chem-Biol Interact 163:145-159

Kazanci N, Severcan F (2007) Concentration dependent different action of tamoxifen on membrane fluidity. Biosci Rep 27:247-255

Kiyotani K, Mushiroda T, Nakamura Y, Zembutsu H (2012) Pharmacogenomics of tamoxifen: roles of drug metabolizing enzymes and transporters. Drug Metab Pharmacokinet 27:122131

Labbe G, Pessayre D, Fromenty B (2008) Drug-induced liver injury through mitochondrial dysfunction: mechanisms and detection during preclinical safety studies. Fund Clin Pharmacol 22:335353

Lemasters JJ, Theruvath TP, Zhong Z, Nieminen AL (2009) Mitochondrial calcium and the permeability transition in cell death. Biochim Biophys Acta 1787:1395-1401

Lim YC, Desta Z, Flockhart DA, Skaar TC (2005) Endoxifen (4-hydroxy$\mathrm{N}$-desmethyl-tamoxifen) has anti-estrogenic effects in breast cancer cells with potency similar to 4-hydroxy-tamoxifen. Cancer Chemother Pharmacol 55:471-478

Lotan R, Neumann G, Lotan D (1980) Relationships among retinoid structure, inhibition of growth, and cellular retinoic acid-binding protein in cultured S91 melanoma cells. Cancer Res 40:1097-1102

Madeira VM (1975) A rapid and ultrasensitive method to measure $\mathrm{Ca}++$ movements across biological membranes. Biochem Biophys Res Commun 64:870-876

Monteiro P, Duarte AI, Goncalves LM, Providencia LA (2005) Valsartan improves mitochondrial function in hearts submitted to acute ischemia. Eur J Pharmacol 518:158-164

Moreira PI, Custodio J, Moreno A, Oliveira CR, Santos MS (2006) Tamoxifen and estradiol interact with the flavin mononucleotide site of complex I leading to mitochondrial failure. J Biol Chem 281:10143-10152

Niu XW, Peng ZH, Feng J, Ma HQ, Liu C, Yuan JY (2005) Mechanism of retinoid receptors in inhibiting proliferation and inducing apoptosis of human melanoma cell line A375. Chin Med J (Engl) 118:1482-1486

Njar VC, Gediya L, Purushottamachar P, Chopra P, Vasaitis TS, Khandelwal A, Mehta J, Huynh C, Belosay A, Patel J (2006) Retinoic acid metabolism blocking agents (RAMBAs) for treatment of cancer and dermatological diseases. Bioorg Med Chem $14: 4323-4340$

Norris RE, Minturn JE, Brodeur GM, Maris JM, Adamson PC (2011) Preclinical evaluation of lestaurtinib (CEP-701) in combination with retinoids for neuroblastoma. Cancer Chemother Pharmacol 68:1469-1475
Notario B, Zamora M, Viñas O, Mampel T (2003) All-trans-retinoic acid binds to and inhibits adenine nucleotide translocase and induces mitochondrial permeability transition. Mol Pharmacol 63:224-231

Oliveira PJ, Wallace KB (2006) Depletion of adenine nucleotide translocator protein in heart mitochondria from doxorubicintreated rats-relevance for mitochondrial dysfunction. Toxicology 220:160-168

Pebay-Peyroula E, Brandolin G (2004) Nucleotide exchange in mitochondria: Insight at a molecular level. Curr Opin Struct Biol $14: 420-425$

Pili R, Salumbides B, Zhao M, Altiok S, Qian D, Zwiebel J, Carducci MA, Rudek MA (2012) Phase I study of the histone deacetylase inhibitor entinostat in combination with 13-cis retinoic acid in patients with solid tumours. Br J Cancer 106:77-84

Rigobello MP, Scutari G, Friso A, Barzon E, Artusi S, Bindoli A (1999) Mitochondrial permeability transition and release of cytochrome $\mathrm{c}$ induced by retinoic acids. Biochem Pharmacol 58:665-670

Ross-Innes CS, Stark R, Holmes KA, Schmidt D, Spyrou C, Russell R, Massie CE, Vowler SL, Eldridge M, Carroll JS (2010) Cooperative interaction between retinoic acid receptor-alpha and estrogen receptor in breast cancer. Genes Dev 24:171-182

Rousseau C, Pettersson F, Couture MC, Paquin A, Galipeau J, Mader S, Miller WH Jr (2003) The N-terminal of the estrogen receptor (ERalpha) mediates transcriptional cross-talk with the retinoic acid receptor in human breast cancer cells. J Steroid Biochem Mol Biol 86:1-14

Sabichi AL, Xu H, Fischer S, Zou C, Yang X, Steele VE, Kelloff GJ, Lotan R, Clifford JL (2003) Retinoid receptor-dependent and independent biological activities of novel fenretinide analogues and metabolites. Clin Cancer Res 9:4606-4613

Saez CG, Velasquez L, Montoya M, Eugenin E, Alvarez MG (2003) Increased gap junctional intercellular communication is directly related to the anti-tumor effect of all-trans-retinoic acid plus tamoxifen in a human mammary cancer cell line. J Cell Biochem 89:450-461

Sardana K, Garg VK (2011) Low-dose isotretinoin in acne vulgaris: A critical review. Br J Dermatol 165:698-700

Sauvez F, Drouin DS, Attia M, Bertheux H, Forster R (1999) Cutaneously applied 4-hydroxytamoxifen is not carcinogenic in female rats. Carcinogenesis 20:843-850

Searovic P, Alonso M, Oses C, Pereira-Flores K, Velarde V, Saez CG (2009) Effect of tamoxifen and retinoic acid on bradykinin induced proliferation in MCF-7 cells. J Cell Biochem 106:473-481

Simeone AM, Tari AM (2004) How retinoids regulate breast cancer cell proliferation and apoptosis. Cell Mol Life Sci 61:1475-1484

Starkov AA (2010) The molecular identity of the mitochondrial Ca2+ sequestration system. FEBS J 277:3652-3663

Stocchi V, Cucchiarini L, Magnani M, Chiarantini L, Palma P, Crescentini G (1985) Simultaneous extraction and reverse-phase high-performance liquid chromatographic determination of adenine and pyridine nucleotides in human red blood cells. Anal Biochem 146:118-124

Toma S, Isnardi L, Raffo P, Dastoli G, De Francisci E, Riccardi L, Palumbo R, Bollag W (1997) Effects of all-trans-retinoic acid and 13-cis-retinoic acid on breast-cancer cell lines: growth inhibition and apoptosis induction. Int J Cancer 70:619-627

Veal G, Rowbotham S, Boddy A (2007) Pharmacokinetics and pharmacogenetics of 13-cis-retinoic acid in the treatment of neuroblastoma. Therapie 62:91-93

Vignais PV (1976) Molecular and physiological aspects of adenine nucleotide transport in mitochondria. Biochim Biophys Acta 456:1-38

Vuletic A, Konjevic G, Milanovic D, Ruzdijic S, Jurisic V (2010) Antiproliferative effect of 13-cis-retinoic acid is associated with 
granulocyte differentiation and decrease in cyclin B1 and Bcl-2 protein levels in G0/G1 arrested HL-60 cells. Pathol Oncol Res 16:393-401

Wallace KB (2008) Mitochondrial off targets of drug therapy. Trends Pharmacol Sci 29:361-366

Wang Y, He QY, Chen H, Chiu JF (2007) Synergistic effects of retinoic acid and tamoxifen on human breast cancer cells: proteomic characterization. Exp Cell Res 313:357-368
Wong ZW, Ellis MJ (2004) First-line endocrine treatment of breast cancer: aromatase inhibitor or antioestrogen? Br J Cancer 90:20-25

Zhou S, Starkov A, Froberg MK, Leino RL, Wallace KB (2001) Cumulative and irreversible cardiac mitochondrial dysfunction induced by doxorubicin. Cancer Res 61:771-777

Zorov DB, Juhaszova M, Yaniv Y, Nuss HB, Wang S, Sollott SJ (2009) Regulation and pharmacology of the mitochondrial permeability transition pore. Cardiovasc Res 83:213-225 